\title{
EDITORIAL
}

\section{Transnational Environmental Law across the Spectrum of Development}

\section{INTRODUCTION}

Few variables shape policy and statecraft more than economic development. Issues of global economic inequality have long vexed the formation and expansion of the public international law of the environment, as Global North and South dispute the relationship between environmental responsibility, economic growth, and state capacity. Environmental advocates tend to regard development with deep ambivalence, concerned by the historic relationship between growth, consumption, and pollution on the one hand, and between underdevelopment, poverty, and human rights concerns on the other. What is clear to all is that development matters, and that its effects are insufficiently understood. This issue of Transnational Environmental Law (TEL) features a set of studies the subjects of which span a range of development contexts and, in so doing, provide important insights into the contours of transnational environmental law across a variety of locales and economies. The first pair of articles focus on states that are often neglected in environmental scholarship. Here we find the law taking shape amidst the threat (or reality) of conflict, a factor too easily overlooked in regions of accelerated development. The second pair of articles, by contrast, returns to discussions about the European Union (EU) and the Paris Agreement, ${ }^{1}$ territory well worked by scholars, but which nonetheless remains fertile soil for new insights into transnational environmental law. Finally, in the last pair of articles the focus shifts to China, where rapid development and burgeoning emissions profiles have radically altered the global environmental conversation.

\section{TRANSNATIONAL LEGAL PRINCIPLES AND PLAYERS IN UNDERDEVELOPED STATES}

Economic development is typically associated with increased state capacity and the maturation of legal and political institutions. A stable and sophisticated institutional environment, in turn, fosters the development of a dynamic support network of nongovernmental organizations (NGOs) where policy is analyzed and mediated for a

1 Paris (France), 12 Dec. 2015, in force 4 Nov. 2016, available at: https://unfccc.int/sites/default/files/english_paris_agreement.pdf. 
broader public. Social movements and policy entrepreneurs interact within this network, with the goal of changing formal policy on issues of concern. Developing states, in contrast, face headwinds in terms of governance and domestic capacity building, and the role and influence of NGOs are decidedly different. In this issue's first article, Nada Ali, Reilly Dempsey Willis, Asim El Moghraby and Mohammaed Jalal Hashim demonstrate convincingly that the diffusion of international norms of environmental justice norms typically championed by international NGOs - often depends crucially on domestic political structures capable of delivering on latent reform potential. ${ }^{2}$

Ali and her co-authors take as their point of departure the relatively optimistic 'Spiral Model' of social mobilization over human rights issues, a model that tends to play up the efficacy of transnational advocacy networks. ${ }^{3}$ In their examination of conflicts over displacement wrought by the 2009 construction of the Merowe Dam on the Nile River in northern Sudan, Ali and her co-authors point out that successful transnational advocacy may itself depend on the pre-existence of certain minimal domestic protections. Their findings somewhat weaken the empirical basis for claims of a positive feedback loop between transnational norm deployment and domestic respect for human rights. Interestingly, the authors also demonstrate how the context of development may allow state actors to exploit the tension between emerging norms of environmental justice and the more established imperative of economic development.

When the government of Sudan completed the 67-metre Merowe Dam, it did so amidst the ongoing dissent and activism of various domestic communities whose displacement was necessitated by the dam. At the heart of the study by Ali and her co-authors are the various approaches taken by these communities over issues of resettlement and compensation. Where certain communities were able to extract tactical concessions from the Sudanese government by mobilizing domestic resistance, others faced armed reprisals. This conflict, which played out over the course of nearly 15 years, resulted in international litigation which the authors characterize as inefficacious. By 'invoking norms based on development and economic growth to justify the building of hydropower dams', Sudanese officials were able to 'fend off' criticism over dam construction and characterize the development project itself as a crucial expression of government concern for secure and sustainable access to water resources across the country. ${ }^{4}$ Thus, the range of transnational legal claims, and the availability of international NGOs to extend them, were ultimately less relevant than the internal political dynamics within Sudan that allowed some communities to win compensation or secure salutary resettlement conditions.

The next article in this issue, co-authored by Mohsen Nagheeby, Mehdi Piri D. and Michael Faure, examines dam development in another locale also beset by recent

2 N. Ali, R.D. Willis, A. El Moghraby \& M.J. Hashim, 'Norms, Mobilization and Conflict: The Merowe Dam as a Case Study' (2019) 8(2) Transnational Environmental Law, pp. 217-45.

3 T. Risse \& K. Sikkink, 'The Socialization of International Human Rights Norms into Domestic Practices: Introduction', in T. Risse, S.C. Ropp \& K. Sikkink (eds), The Power of Human Rights: International Norms and Domestic Change (Cambridge University Press, 1999), pp. 1-38.

$4 \quad$ Ali et al., n. 2 above, pp. 234-5. 
conflict. ${ }^{5}$ The Harirud River Basin encompasses populated regions of Iran (including Mashhad, the nation's second-most populous city), Turkmenistan, and Afghanistan. All three states depend heavily on the river for domestic water supply and agricultural irrigation. In 2016, after years of fruitless attempts at negotiation, upstream Afghanistan opened the Salma Dam, realizing the fears of the two downstream (and more economically developed) states. Like Sudan in the case described above, Afghanistan rests its claim for the necessity of the dam on its relatively low level of development. The authors' concern is both the legality of the dam and its legitimacy under broad principles of international order.

Plans for the Salma Dam date back to 1976, when both India and Britain expressed support for the construction of an Afghan dam on the Harirud to expand agricultural output in the region. When construction actually began in 2001, Iran and Turkmenistan invited Afghanistan to join in negotiations for trilateral cooperation in basin management. This, and later invitations, went unanswered until 2017, when Afghanistan engaged in bilateral negotiations with both states, which, however, have not yet resulted in any formal agreement. Moreover, none of the three states have acceded to either of the two treaties most directly relevant to the issues raised by the dam: the United Nations Watercourses Convention ${ }^{6}$ and the United Nations Economic Commission for Europe Convention on the Protection and Use of Transboundary Watercourses and International Lakes. ${ }^{7}$ Yet, the authors argue that the principles at the core of these treaties, as to both substance and procedure, now serve as customary international law binding upon all states. Specifically, procedural principles - notably the duty to cooperate and to notify - must be observed in order to give appropriate effect to the substantive principles of no harm and of equitable and reasonable utilization among co-riparian states.

Applying these principles to the Salma Dam, the authors conclude that Afghanistan has not complied with its international obligations. Its failure to cooperate in basin management with Turkmenistan and Iran prevents it from understanding and responding to the range of possible harmful impacts that the operation of the dam will eventually inflict. These impacts, the authors concede, are at the moment speculative (although modelling efforts suggest that the matter of harm is not a question of if but of when and how much)..$^{8}$ Nevertheless, the argument provides a helpful window into the normative force of customary international principles, rather than formally binding enactments, as applied to the legitimacy of unilateral development projects. Observers might expect such arguments to proliferate as major development projects unfold across developing regions, particularly on transboundary waters.

5 M. Nagheeby, M. Piri D. \& M. Faure, 'The Legitimacy of Dam Development in International Watercourses: A Case Study of the Harirud Water Basin' (2019) 8(2) Transnational Environmental Law, pp. 247-78.

6 Formally, the United Nations Convention on the Law of the Non-navigational Uses of International Watercourses, New York, NY (United States (US)), 21 May 1997, in force 17 Aug. 2014, available at: http://legal.un.org/ilc/texts/instruments/english/conventions/8_3_1997.pdf.

7 Helsinki (Finland), 17 Mar. 1992, in force 6 Oct. 1996, available at: http://www.unece.org/env/water.

8 Nagheeby, Piri D. \& Faure, n. 5 above, pp. 272-3. 


\section{FIRST-WORLD PROBLEMS? CLIMATE LAW IN MATURE ECONOMIES}

Regular readers of TEL well know that, for all the journal's attention to underappreciated corners of environmental policy, there are mainstays of transnational environmental law to which our attention must return time and again. The next two articles in this issue reflect matters of long-standing concern - but do so in ways that exemplify how legal and technological innovations create new dynamics in established domains.

Ana López-Rodríguez starts us off with a cautionary tale about renewable energy investment within the EU. ${ }^{9}$ Her insightful article warns of lurking tensions between bilateral or multilateral investment treaties (BITs or MITs) on the one hand, and EU law on the other. More specifically, López-Rodríguez fears that recent EU decisions may have the perverse effect of dampening investment in renewable energy at a time when it is sorely needed. A great deal of renewable investment is conducted under BITs, but EU institutions 'have thrown a spanner in the works' by enforcing EU competition rules over and against conflicting awards of damages granted pursuant to investor-state arbitration. ${ }^{10}$ At the core of her concern is the wave of claims brought by renewable energy firms in the wake of policy retrenchment during the global financial crisis of 2008 . Following that crisis, certain feed-in tariffs and other policies favourable to renewables were trimmed or amended, leading the affected firms to commence arbitration.

López-Rodríguez begins by emphasizing the importance of a stable cross-border investment environment in general, and of due regard for arbitral outcomes in particular. Drawing on a range of cases and pronouncements in recent years, she notes the various ways in which BITs, particularly those between EU Member States, sit in an uneasy relationship with EU law. She then makes the normative argument that EU law ought not and need not regard arbitral awards as state aid, warning that renewable investors may invest elsewhere if they cannot obtain relief under existing trade agreements. ${ }^{11}$ The latter portion of her article is devoted to a thorough analysis of the legal issues raised, firstly, by the enforcement of arbitral awards under EU law; and, secondly, by the creation of a permanent international investment tribunal (as a replacement for current investor-state dispute resolution mechanisms). Although there is support for such a Multilateral Investment Court (MIC), 'its conformity with EU law is far from clear'. ${ }^{12}$ As to policy, López-Rodríguez carefully avoids taking a position on a possible MIC, but nonetheless notes that renewable investors have expressed a strong general preference for the present system based on arbitration. Her analysis clearly suggests that, notwithstanding the pressures for reform, the strength of the EU commitment to climate change mitigation may warrant the prioritization of a coherent, renewable-friendly foreign investment policy over stringent competition rules. More generally, her article is an important reminder

9 A.M. López-Rodríguez, 'The Sun Behind the Clouds? Enforcement of Renewable Energy Awards in the EU' (2019) 8(2) Transnational Environmental Law, pp. 279-302.

10 Ibid., p. 285.

11 Ibid., p. 291.

12 Ibid., p. 299. 
that the fraught relationship between public policy and private investment bears not only on carbon-intensive firms, but also on environmentally friendly ones.

Just as renewable technologies offer hope for emissions reduction, so advances in remote sensing technology present an opportunity for substantial improvements in emissions measurement. Accurate reporting and measurement of emissions inventories are crucial for the integrity of the global regulatory regime, and satellite observation now makes it possible to measure surface concentrations of greenhouse gases (GHGs) with more granularity than ever before. In their article in this issue, Timiebi Aganaba-Jeanty and Anna Huggins examine the potential for satellite-based measurements to contribute to transparency, accountability, and answerability for state GHG emissions. ${ }^{13}$ Because international space law permits remote sensing without the permission of the state being observed, the authors foresee clear transparency benefits from the use of satellites. The distribution of any resulting data will contribute to public answerability, in the form of non-state actors conducting unofficial and informal oversight 'naming and shaming' actors whose emissions have been under-reported.

What is less clear, however, is whether satellite-enabled measurements can soon contribute to improvements in the broader operation of the Paris Agreement. ${ }^{14}$ No doubt some states will use satellite-based techniques to verify their own emissions reports in compliance with the Agreement, but the authors describe several difficulties that could impede more wide-ranging reliance on satellite measurements. Firstly, the current process by which expert review teams assess state-submitted emissions data does not allow experts to make use of independent data sources. Thus satellite data has the potential to considerably enhance the robustness of the technical expert review processes under the Paris Agreement', but such potential remains unrealized at present. ${ }^{15}$ A second impediment is that satellite measurement approaches could be understood to lack the deference to national sovereignty required by the Agreement, if the observed state does not consent to remote sensing and observation. Thirdly, because satellite-launching capability presently exists among a limited pool of states, others may harbour justifiable concerns about the independence and integrity of the resulting data. Nonetheless, the authors suggest that atmospheric measurement technology holds real promise, and may soon provide a standardized, independent platform whereby states can be held accountable for their pledged emissions reductions under the Paris Agreement.

\section{ENVIRONMENTAL LITIGATION IN CHINA}

The final two articles in this issue return our attention to China, where the developmental trajectory over the past several decades has been unparallelled. China's rapid growth, increasing emissions, and global power already make it an obvious target for study by environmental scholars, and recent changes in Chinese environmental

13 T. Aganaba-Jeanty \& A. Huggins, 'Satellite Measurement of GHG Emissions: Prospects for Enhancing Transparency and Answerability under International Law' (2019) 8(2) Transnational Environmental Law, pp. 303-26.

14 N. 1 above.

15 Aganaba-Jeanty \& Huggins, n. 13 above, p. 322. 
law only augment its importance. In their article, Qi Gao and Sean Whittaker examine one of the most noteworthy developments in Chinese environmental law: recent legislation in China authorizing public interest litigation (PIL) by both NGOs and various public actors. ${ }^{16}$ The authors express reservations regarding this development, noting that apparent benefits obscure significant impediments.

To understand why, one must first note that the relevant legislation authorizes PIL not only by NGOs, but also by administrative authorities and procuratorates (which bear a degree of similarity with the office of public prosecutor). Rules of standing were relaxed for all three sets of actors in a fashion which, though reminiscent of the 'objective legality' model of judicial action, ultimately embedded a sort of contradiction within the jurisprudence of PIL. Gao and Whittaker demonstrate that expanded standing for administrative authorities, which generally litigate on behalf of state ownership interests rather than in pursuit of authentically public concerns, has the effect of 'crowding out' litigation efforts by NGOs, which are likely to represent the public interest. ${ }^{17}$ PIL brought by procuratorates is perhaps even more parasitic upon PIL brought by NGOs: although Chinese law requires procuratorates to provide a 30-day notice period to environmental NGOs, ostensibly evincing a preference for NGO litigation, the incentives facing procuratorates incline them to initiate enforcement action themselves. This might be superficially acceptable, but procuratorates are not fully independent from the Chinese state and thus 'could be manipulated as a new tool to invade individual rights or overlook particular instances of environmental damage'. ${ }^{18}$

Worse, the aggrandizement of administrative authorities and procuratorates may have the effect of retarding the development of a vigorous environmental presence in Chinese civil society. Gao and Whittaker express concern not only that PIL brought by government actors will fail to defend the public interest, but that it will prevent environmental NGOs from maturing and assuming a forceful and enduring role. The authors end their article by describing the many hurdles that NGOs face in bringing PIL despite the liberalized rules of standing that have garnered so much acclaim worldwide. Thus, reforms that appeared 'intended to empower civil society ... actually weaken it'. ${ }^{19}$

In the final article of this issue, Yue Zhao, Shuang Lyu and Zhu Wang also examine litigation in the Chinese state. Specifically, they seek to characterize climate change litigation (CCL). ${ }^{20}$ They concede from the start that CCL in the well-studied common law context (the United States (US) and Australia, in particular) is a very different beast from that found in China, 'an authoritarian country with civil law traditions' ${ }^{21}$ In the former, courts are often presented as 'alternative suppliers of climate change regulation, stepping up where

16 Q. Gao \& S. Whittaker, 'Standing to Sue Beyond Individual Rights: Who Should Be Eligible to Bring Environmental Public Interest Litigation in China?' (2019) 8(2) Transnational Environmental Law, pp. 327-47.

17 Ibid., pp. 333-6.

18 Ibid., p. 339.

19 Ibid., p. 347.

20 Y. Zhao, S. Lyu \& Z. Wang, 'Prospects for Climate Change Litigation in China' (2019) 8(2) Transnational Environmental Law, pp. 349-77.

21 Ibid., p. 377. 
government regulation falters' ${ }^{22}$ In China, however, the authors find the judiciary acting as a constructive collaborator in the regulatory process, engaged with government policy and the application of relevant law, rather than as a separate venue for the actuation of environmental obligations.

The authors' study is based on their structured sample of Chinese CCL cases decided between 2011 and 2018. As expected, the composition of the sample differs markedly from what one might find in a decentralized state, where private actions against the state dominate the climate docket. Chinese CCL features instead numerous contractual disputes between entities finding their way amidst new policies aimed at bringing about a low-carbon economy. Here we see, for example, a taxi company prevailing in a dispute regarding the termination of a contract between the company and a driver whose heavily-polluting vehicle added to the company's tax burden. ${ }^{23}$ Neither party in such a dispute seeks principally to advance or affect state policy; instead, it is the court itself advancing the state's carbon-reduction agenda, but doing so in a decidedly supporting role relative to judicial counterparts elsewhere.

In addition, in most recent years Chinese courts have confronted a 'new judicial phenomenon', namely, tort-based litigation addressing China's notorious air pollution. ${ }^{24}$ Thanks to a statutory expansion of PIL - the expansion described by Gao and Whittaker above - NGOs, procuratorates, and provincial governments may now bring civil actions against polluters and, as they do, they will benefit from a recent relaxation in the prevailing standard for the establishment of causation. Notwithstanding the concerns described by Gao and Whittaker, Zhao, Lyu and Wang express optimism that PIL of these forms could become a 'substitute or a gateway' to Chinese CCL, ${ }^{25}$ even though GHG emissions are not presently actionable under standard air pollution regulation. 'Current Chinese regulations for GHG emissions', the authors note, 'function generally on the basis of voluntary reduction mechanisms', and thus presently fall outside the scope of tort claims activity. ${ }^{26}$ Even so, this expansion of PIL may suggest the opening of a new sphere of influence for Chinese courts with regard to climate change-and, if so, serve as a marker of institutional convergence in developed contexts.

Editors-in-Chief

Thijs Etty

Veerle Heyvaert

Editors
Cinnamon Carlarne
Bruce Huber
Jacqueline Peel
Josephine van Zeben

$\begin{array}{ll}22 & \text { Ibid., p. } 351 . \\ 23 & \text { Ibid., p. } 359 . \\ 24 & \text { Ibid., p. } 366 . \\ 25 & \text { Ibid., p. } 374 . \\ 26 & \text { Ibid., p. } 376 .\end{array}$ 